\title{
TRACER STUDY \\ ALUMNI JURUSAN PERBANKAN SYARIAH FAKULTAS EKONOMI DAN BISNIS ISLAM IAIN WALISONGO SEMARANG
}

\author{
Johan Arifin
}

\begin{abstract}
Abstrak
Salah satu cara untuk mengukur keberhasilan institusi pendidikan dalam menghasilkan kualitas lulusan adalah dengan melaksanakan survei penelusuran alumni (tracer study). Hal ini berguna untuk mengukur kompetensi lulusan yang bermutu tinggi dan relevan dengan kebutuban pasar, meningkatkan kualitas tata kelola yang kedibel, transparan dan akuntabel, dan cara untuk mengetahui perubahan dan kebutuban akan kemampuan dan kapabilitas yang sesuai dengan kondisi di dunia praktis yang kompleks melalui pendapat alumninya. Di sisi lain, tracer study juga berguna untuk memperoleh informasi tentang kekurangan yang mungkin terjadi dalam proses pendidikan.
\end{abstract}

Kata kunci: tracer study, kompetensi, alumni, dunia kerja

\section{Pendahuluan}

Lembaga pendidikan, termasuk institusi pendidikan tinggi dituntut untuk selalu melakukan evaluasi diri guna menjaga relevansi program pengembangan akademiknya sesuai dengan peran yang diembannya. Tuntutan akan kompetensi lulusan yang sesuai dengan kebutuhan pasar kerja serta perkembangan sains dan teknologi menjadi faktor pendorong untuk melakukan perbaikan perencanaan, seleksi penerimaan mahasiswa baru, proses pelaksanaan akademik dan internal manajemen untuk mendukung tercapainya visi dan misi institusi pendidikan.

Berkaitan dengan hal tersebut Program Studi Perbankan Syariah sebagai unit pelaksana akademik di lingkungan IAIN Walisongo dituntut pula untuk senantiasa menyesuaikan .diri dengan gerak perkembangan induknya dalam hal 
Tracer Study Jurusan Perbankan Syariah

program pengembangan akademik agar mutu lulusan dapat ditingkatkan sesuai dengan tuntutan zaman, serta peran serta staf akademiknya mampu menjabarkan visi dan misi lembaga menjadi suatu tindakan nyata yang dapat dirasakan manfaatnya oleh para pengguna (stakeholder).

Institus pendidikan tinggi diharapkan menghasilkan lulusan yang berkualitas sehingga mampu berkarya dengan baik dalam dunia praktis. Situasi lingkungan eksternal yang semakin turbulen dan kompetitif menimbulkan sejumlah kekhawatiran akan tidak mampunya lulusan perguruan tinggi memenuhi berbagai tuntutan dan kebutuhan di dunia kerja. Banyak lulusan perguruan tinggi yang menganggur karena kompetensi keahlian mereka tidak sesuai dengan kebutuhan pasar tenaga kerja, dan mereka yang menganggur umumnya lulusan program studi ilmu-ilmu sosial.

Salah satu cara untuk mengukur keberhasilan institusi pendidikan dalam menghasilkan kualitas lulusan adalah dengan melaksanakan survei penelusuran alumni (tracer study). Selain mengukur kompetensi lulusan yang bermutu tinggi dan relevan dengan kebutuhan pasar kerja, penelusuran alumni juga untuk dapat berguna untuk meningkatkan kualitas tata kelola yang kredibel, transparan dan akuntabel.

Kegiatan penelusuran alumni juga merupakan pemenuhan standar yang telah dipersyaratkan oleh Badan Akreditasi Nasional Perguruan Tinggi (BAN PT). Namun demikian, standar yang ditetapkan oleh BAN PT merupakan standar normatif yang belum mampu mengukur sinyal dari dunia kerja. Hasil penelusuran alumni dapat dijadikan umpan balik untuk mendisain kembali kurikulum, memperbaiki proses pembelajaran dan peningkatan fasilitas pembelajaran untuk mengantisipasi perubahan dunia kerja.

Hasil penelusuran alumni juga dapat digunakan untuk mengetahui tingkat relevansi antara program pendidikan yang diselenggarakan oleh sebuah institusi pendidikan (termasuk perguruan tinggi) dengan kebutuhan lapangan. Dari studi penelusuran seperti itu akan diperoleh berbagai informasi penting, antara lain kebutuhan riil yang diperlukan dunia kerja, kekurangan yang dimiliki lulusan, kelemahan kurikulum yang selama ini digunakan, dan harapan alumni terhadap almamaternya terkait dengan penyelenggaraan pendidikan ke depan. 
Penelusuran alumni merupakan salah satu cara bagi institusi pendidikan tinggi untuk mengetahui perubahan dan kebutuhan akan kemampuan dan kapabilitas yang sesuai dengan kondisi di dunia praktis yang kompleks melalui pendapat alumninya. Penelusuran alumni juga merupakan pendekatan yang memungkinkan institusi pendidikan tinggi untuk memperoleh informasi tentang berbagai kekurangan yang mungkin terjadi dalam proses pendidikan dan proses pembelajaran dan dapat merupakan dasar untuk perencanaan aktivitas untuk penyempurnaan di masa mendatang. ${ }^{1}$

Hasil penelusuran alumni diharapkan dapat digunakan sebagai masukan untuk meningkatkan relevansi dan efektivitas program akademik dan perbaikan fasilitas pembelajaran. Oleh karena itu, penelusuran alumni merupakan salah satu mekanisme bagi lembaga pendidikan tinggi untuk mampu mempersiapkan alumninya dalam menghadapi persaingan global dunia kerja di masa yang akan datang.

Beberapa permasalahan mendasar mengenai masalah kompetensi, dapat diidentifikasi beberapa akar permasalahan terkait dengan lulusan yang sudah dihasilkan oleh prodi Perbankan Syariah IAIN Walisongo, diantaranya adalah: a) Minimnya informasi tentang kinerja lulusan; b) Belum tersedia data tentang jenis-jenis pekerjaan yang diperoleh lulusan; c) Belum diperoleh data tentang penyebaran lulusan; c) Belum diperoleh informasi tentang kompetensi yang diperlukan lapangan kerja bagi lulusan; d) Belum diperoleh informasi tentang kesesuaian kompetensi lulusan Perbankan syariah dengan kebutuhan lapangan; e) Belum diperoleh informasi tentang kendala yang dihadapi lulusan dalam memperoleh pekerjaan serta mengembangkan diri setelah lulus.

Adapun tujuan dari penelitian adalah: (1) untuk mengetahui gambaran karir alumni yang mencakup profil kompetensi, kesesuaian bidang kerja dengan bidang studi, serta masukan dari alumni untuk pengembangan kurikulum program studi ke depan, (2) memberikan rekomendasi atau saran yang diberikan untuk Pengembangan Fakultas Ekonomi dan Bisnis Islam IAIN Walisongo.

1 Zembere, S.N. dan Chinyama, MPM, The University of Malawi Graduate Tracer study 1996. http://aau.org/studyprogram/notpub. 24 Agustus 2008 
Tracer Study Jurusan Perbankan Syariah

\section{Studi Penelusuran}

Penelusuran lulusan (tracer study) merupakan bagian penting dari aktivitas sebuah lembaga pendidikan. Melalui penelusuran lulusan akan diperoleh berbagai informasi penting yang sangat bermanfaat bagi lembaga pendidikan yang bersangkutan, bagi para lulusan, dan juga lembaga-lembaga lain yang terkait dengan penyelenggaraan pendidikan. Tracer study memungkinkan sebuah lembaga pendidikan melacak kondisi lulusan yang dihasilkan dan dari informasi yang diperoleh dapat diambil berbagai kebijakan dan tindakan yang memberikan manfaat bagi para lulusan dan bagi pengembangan lembaga yang bersangkutan. Salah satu manfaat penting dari penelitian tracer study adalah diperolehnya informasi tentang relevansi program pendidikan yang diselenggarakan dengan kebutuhan lapangan.

Objek utama studi penelusuran alumni adalah meneliti proses transisi dari pendidikan tinggi ke dunia kerja, analisis hubungan antara pendidikan tinggi dengan dunia kerja dari sudut pandang tujuan individu seperti kepuasan kerja dan posisi kerja, pendapatan, jaminan kerja dan jenis pekerjaan. ${ }^{2}$ Faktor penting yang berkaitan dengan kesuksesan lulusan adalah jender, motivasi kerja, kualifikasi studi dan kondisi pasar kerja, evaluasi berdasarkan pengalaman dan pandangan dari lulusan, fasilitas dan kurikulum dan umpan balik dari lulusan. Studi penelusuran memiliki arti penting menjamin keberlangsungan proses evaluasi penampilan jurusan atau program studi dan mengetahui perkembangan jurusan atau program studi melalui pembandingan hasil studi penelusuran pertama dengan hasil studi penelusuran berikutnya. SEARCA menambahkan bahwa studi penelusuran mempengaruhi pengembangan sumber daya manusia melalui program jangka pendek dan jangka panjang dan menjaga kualitas lulusan yang berdampak secara individual, institusi maupun negara. ${ }^{3}$

Nazir menggolongkan studi penelusuran termasuk dalam metode deskriptif berkesinambungan yaitu meneliti secara deskriptif secara terusmenerus suatu objek penelitian. ${ }^{4}$ Penelitian ini biasanya dilakukan dalam

${ }^{2} \mathrm{Ibid}, \mathrm{hlm} .2$

${ }^{3}$ SEARCA, "Tracer study on SEARCA Fellows and UC Grantees", http://aau.org/studyprogram/web/scholarship, diakses 24 Agustus 2008

${ }^{4}$ M. Nazir, Metode Penelitian, Jakarta: Ghalia Indonesia, 1999, hlm. 65-66 
meneliti masalah-masalah sosial. Fokus utama dari studi penelusuran adalah memperoleh informasi dari lulusan yang sudah bekerja atau belum bekerja, sebagai bahan pengambilan kebijakan dalam rangka pengembangan atau penyempurnaan suatu institusi. Jadi, studi penelusuran adalah studi yang meneliti hubungan antara pendidikan tinggi dengan dunia kerja dari sudut pandang tujuan individu seperti kepuasan kerja dan posisi kerja, pendapatan, jaminan kerja dan jenis pekerjaan. Fokus utamanya adalah memperoleh informasi dari lulusan yang sudah bekerja atau belum bekerja.

Studi penelurusan bertujuan untuk mengetahui mobilitas tamatan dan kepuasan tamatan terhadap pekerjaannya. Mobilitas tamatan dapat dilihat dari mobilita karir, baik secara vertikal maupun horizontal. Mobilitas karir secara vertikal dapat ditelusuri melalui jenjang jabatan pekerjaan yang diperoleh tamatan sedangkan mobilitas horizontal ditelusuri melalui banyaknya tamatan yang melakukan perpindahan tempat kerja. Berdasarkan hasil penelusuran lulusan, sekolah dapat melakukan berbagai tindakan yang diharapkan mampu meningkatkan kualitas sekolah yang bersangkutan.

Pemanfaatan hasil studi penelusuran juga memungkinkan sekolah melakukan perubahan dan penyesuaian sehingga sustainabilitas sekolah lebih menjamin. Slamet PH mengemukakan bahwa studi penelusuran bertujuan untuk mengetahui: sejarah karir tamatan, status karir/pekerjaan tamatan, dan penilaian tamatan terhadap program pendidikan atas dasar pengalaman kerja mereka. Meyer, dkk. mengklasifikasi tujuan studi penelusuran menjadi tiga hal: 1) untuk memperbaiki pengajaran dan pembelajaran di sekolah, 2) untuk membantu alumni dalam mencari pekerjaan, dan 3) untuk mengumpulkan informasi penting sehingga dapat digunakan untuk memperbaiki program.

\section{Konsep Pengembangan Organisasi}

Dalam penggunaan sehari-hari, istilah pengembangan sering
digabungkan dengan penelitian sehingga menjadi penelitian dan
pengembangan organisasi. Hal ini dapat dimengerti karena pengembangan
organisasi memang erat kaitannya dengan aktivitas penelitian sehingga masuk
akal apabila kedua kegiatan tersebut digabungkan. Pada sejumlah organisasi,
aktivitas tersebut ditangani oleh bagian khusus yang sengaja dibentuk untuk 
Tracer Study Jurusan Perbankan Syariah

itu. Istilah yang digunakan untuk menamakan bagian tersebut bermacammacam. Di Indonesia, sebutan yang banyak digunakan ialah bagian penelitian dan pengembangan organisasi (balitbang).

Dari studi tentang organisasi dijumpai berbagai batasan tentang istilah pengembangan organisasi. Pada umumnya orang mengartikan pengembangan organisasi sebagai konsep yang menunjuk kepada proses penyiapan dan pengelolaan perubahan melalui penerapan ilmu tingkah laku (behavior science). Sementara itu Rush ${ }^{5}$ mendefinisikan pengembangan organisasi sebagai salah satu proses perubahan kebudayaan, sistem, dan tingkah laku organisasi yang dilakukan secara terencana, terarah, dan sistematik, guna meningkatkan keefektifan organisasi dalam memecahkan problem-problem yang timbul dan dalam mencapai tujuan yang telah ditentukan. Jadi sekurang-kurangnya terdapat tiga hal yang mencirikan pengembangan organisasi, yaitu :

a. Bahwa pengembangan organosasi merupakan suatu proses perubahan.

b. Perubahan tersebut dilakukan secara sengaja, artinya memang dikendaki dan direncanakan.

c. Proses tersebut bertujuan meningkatkan keefektifan organisasi.

Secara lebih terinci, Beer ${ }^{6}$ mengemukakan bahwa pengembangan organisasi merupakan suatu proses pengumpulan data, diagnosis, perencanaan tindakan, intervensi dan perubahan, serta evaluasi hasil, yang diterapkan pada keseluruhan organisasi atau sebagian dari komponen-komponennya. Proses itu dimaksudkan untuk :

a. Meningkatkan integrasi dan keserasian antar struktur, proses strategi, orang, dan budaya dalam organisasi

b. Mengembangkan kreativitas pemecahan masalah organisasi.

c. Mengembangkan kemampuan organisasi dalam memperbaharui diri sehingga sanggup menyesuaikan dengan perubahan yang terjadi diluar organisasi (faktor eksternal).

5 J.L. Gibson, J.M Ivancevich \& J.H. Donelly, Jr, Organizations: Behavior, Structure, Processes. Plano: Business Publications Inc, 1988, hlm. 693-694

${ }^{6}$ J.B. Minner, The Principle of Management. Columbus: Charles E.Merill Publishing Company, 1985, hlm. 321 
Johan Arifin

\section{Tujuan Pengembangan Organisasi}

Tujuan pengembangan organisasi secara garis besar dapat dibedakan menjadi dua, yaitu (1) meningkatkan keefektifan organisasi, dan (2) meningkatkan kepuasan kerja bagi para anggota. French ${ }^{7}$ mengemukakan tujuan pengembangan organisasi secara lebih rinci, yang meliputi :

a. Mempertinggi tingkat kepercayaan dan dukungan diantara para anggota organisasi.

b. Menumbuhkan konflik sehingga mencapai tingkat optimal dalam memecahkan masalah organisasi, baik dalam maupun antar kelompok.

c. Menciptakan kondisi yang memungkinkan anggota memperoleh pengetahuan dan keterampilan tertentu sehingga memperkuat kewenangan resmi yang diperolehnya lewat jalur formal.

d. Mempertinggi tingkat keterbukaan komunikasi, baik yang bersifat horizontal, vertikal maupun diagonal.

e. Mempertinggi tingkat antuisiasme pribadi dan kepuasan anggota dalam organisasi.

f. Menemukan pemecahan problem secara terpadu.

g. Mempertinggi rasa tanggung jawab anggota baik dalam kedudukannya sebagai pribadi maupun kelompok, dalam rangka perencanaan dan pelaksanaan tugas-tugas organisasi.

Jika diperhatikan, apa yang dikemukakan French di atas ternyata banyak berhubungan dengan faktor manusia dalam kedudukannya sebagai anggota organisasi. Dengan demikian dapat dikemukakan bahwa pengembangan organisasi merupakan upaya peningkatan keefektifan organisasi dengan penekanan pada faktor manusianya.

\section{Asumsi Dasar dalam Pengembangan Organisasi}

Program pengembangan organisasi akan berhasil mencapai sasaran yang diharapkan jika kondisi yang dihadapi sesuai dengan asumsi-asumsi berikut :

a. Asumsi tentang individu

${ }^{7}$ Matteson, M.T. et.al, Management and Organizational Behavior Classics. Homewood: BPI/IRWIN, 1989, hlm. 510

Volume VI/Edisi 2/Oktober 2015 
Tracer Study Jurusan Perbankan Syariah

- Pada umumnya individu memiliki dorongan untuk tumbuh dan berkembang; dan dorongan tersebut dapat dipenuhinya lewat lingkungan yang mendukung serta menantang.

- Pada umumnya individu ingin dan mampu memberikan sumbangan dalam rangka mencapai tujuan organisasi, jauh lebih besar dari yang dimungkinkan oleh lingkungan organisasi.

b. Asumsi tentang individu dalam kelompok.

- Pada umumnya individu ingin diterima sebagai anggota kelompok dan berorientasi pada sekurang-kurangnya satu kelompok, misalnya kelompok kerja dan keluarga.

- Salah satu kelompok yang secara psikologis relevan bagi sebagian besar orang ialah kelompok kerja (kelompok tempat mereka bekerja), termasuk di dalamnya teman-teman sejawat dan atasan.

- Pada umumnya orang memiliki kemampuan yang cukup besar untuk meningkatkan keefektifan dalam membantu kelompoknya memecahkan problem yang dihadapi dan bekerjasama secara efektif di dalamnya.

- Untuk mengoptimalkan keefektifan suatu kelompok, pimpinan tidak dapat melaksanakan fungsi-fungsi kepemimpinannya pada semua situasi dan waktu; dan seluruh anggota kelompok harus saling membantu satu sama lain dengan menunjukkan tingkahlaku dan kepemimpinan yang efektif.

c. Asumsi tentang individu dalam organisasi sebagai suatu system.

- Organisasi cenderung dicirikan oleh adanya kerancuan saling ketergantungan kelompok kerja, dan kurang jelasnya fungsi penghubung yang dimiliki oleh pengawas maupun pimpinan yang lain.

- Apa yang terjadi dalam organisasi sebagai keseluruhan mempengaruhi kelompok-kelompok kecil yang ada di dalamnya. Demikian juga sebaliknya, apa yang terjadi pada kelompok-kelompok kecil mempengaruhi organisasi secara leseluruhan.

- Apa yang terjadi pada salah satu bagian organisasi (yaitu aspek-aspek: sosial, teknologi, maupun administratif) mempengaruhi dan juga dipengaruhi oleh bagian lain. 
- Budaya yang ada pada kebanyakan organisasi cenderung menekan perasaan anggota dalam memandang sesama rekannya, organisasi, dan diri mereka sendiri.

- Perasaan yang tertekan tersebut mempengaruhi cara pemecahan masalah, pertumbuhan pribadi, dan kepuasan kerja anggota.

- Tingkat kepercayaan, dukungan, dan kerjasama antar pribadi pada kebanyakan organisasi jauh lebih rendah dari yang diperlukan organisasi.

- Strategi “menang-kalah" (win-lose) dalam memecahkan problem organisasi bukan merupakan strategi optimal yang menguntungkan untuk jangka panjang, meskipun pada situasi-situasi tertentu cocok diterapkan.

- Pemecahan problem secara terpadu dapat dilakukan dengan frekuensi yang jauh lebih tinggi dari pada yang senyatanya dilakukan oleh kebanyakan organisasi.

- Pandangan bahwa faktor perasaan merupakan sesuatu yang penting bagi organisasi cenderung membuka jalan bagi pengembangan tujuan, kepemimpinan, komunikasi, pemecahan masalah, kerjasama dalam kelompok, dan moral.

- Peningkatan penampilan (output) melalui pengembangan organisasi memerlukan dukungan berupa perubahan yang tepat dalam hal: penghargaan, kompensasi, latihan, penempatan, dan spesialisasi tugas anggota. Pendeknya, dalam keseluruhan sistem kepegawaian.

Proses berlangsungnya pengembangan organisasi berjalan di atas berbagai asumsi yang disebutkan di atas. Kadar keberhasilan pengembangan organisasi ditentukan oleh tingkat kesesuaian situasi yang senyatanya dihadapi dengan situasi yang tergambar dalam berbagai asumsi tersebut. Semakin jauh perbedaan antara ke dua situasi tersebut, semakin kecil kemungkinan berhasilnya pencapaian tujuan pengembangan organisasi. Sebagai contoh, salah satu asumsi dasar tentang individu mengatakan bahwa orang memiliki keinginan dan kemampuan untuk memberikan sumbangan dalam rangka pencapaian tujuan organisasi. Jika dalam kenyataannya anggota organisasi tidak 
Tracer Study Jurusan Perbankan Syariah

memiliki keinginan untuk membantu organisasi dalam mencapai tujuannya (meskipun dia sendiri sebenarnya mampu) maka tujuan pengembangan organisasi, yaitu meningkatkan keefektifan organisasi, tidak akan tercapai. Atau bisa jadi anggota berkeinginan menyumbang pencapaian tujuan organisasi, tetapi karena ia tidak memiliki kemampuan untuk itu, maka kondisi ini pun tidak mendukung pencapaian tujuan pengembangan organisasi.

\section{Pengembangan Kurikulum}

Dasar dari pengembangan kurikulum adalah adanya evaluasi kurikulum yang telah ada. Sudjana ${ }^{8}$ mengungkapkan bahwa evaluasi kurikulum bertujuan menilai suatu kurikulum sebagai program pendidikan untuk menentukan efisiensi, efektivitas, relevansi dan produktivitas program dalam mencapai tujuan pendidikan.

Efisiensi berkenaan dengan penggunaan waktu, tenaga, sarana dan sumber-sumber lainnya secara optimal. Efektivitas berkenaan dengan pemilihan atau penggunaan cara atau jalan utama yang paling tepat dalam mencapai suatu tujuan. Relevansi berkaitan dengan kesesuaian suatu program dan pelaksanaannya dengan tuntutan dan kebutuhan baik dari kepentingan masyarakat maupun anak didik. Produktivitas berkaitan dengan optimalnya hasil yang dicapai dari suatu program.

Hasil dari evaluasi kurikulum akan memberi masukkan mengenai perlu atau tidaknya melakukan pengembangan kurikulum. Pengembangan kurikulum perlu dilakukan mengingat kurikulum sebagai alat untuk mencapai tujuan, harus menyesuaikan diri dengan perkembangan masyarakat yang selalu berubah dan terus berkembang. ${ }^{\text {Nasution }}{ }^{10}$ membagi dua istilah untuk pengembangan kurikulum yaitu perubahan dan perbaikan. Perubahan mengacu pada pergeseran posisi, kedudukan atau keadaan yang mungkin membawa perbaikan akan tetapi dapat juga memperburuk keadaan. Perbaikan berarti meningkatkan nilai atau mutu. Konteks pengembangan kurikulum lebih

\footnotetext{
${ }^{8}$ N. Sudjana, Pembinaan dan Pengembangan Kurikulum di Sekolah. Bandung: Sinar Baru Algensindo, 2005, hlm. 49

9 Ibid, hlm. 145

${ }^{10}$ S. Nasution, Asas-asas Kurikulum, Jakarta: Bumi Aksara, 2003, hlm. 122
} 
mengacu pada pendapat Nasution tentang perbaikan yaitu meningkatkan nilai atau mutu kurikulum.

Nasution $^{11}$ mengungkapkan bahwa faktor keberhasilan pengembangan kurikulum yaitu penerimaan masyarakat, "kebudayaan" guru dan rensponsif terhadap kebutuhan masyarakat dan guru. Penerimaan masyarakat berpengaruh pada pengembangan kurikulum karena tanpa adanya penerimaan dari masyarakat terhadap materi kurikulum akan berpengaruh pada kegagalan penerapan kurikulum. Pengembangan kurikulum juga harus disesuaikan dengan "budaya" guru yaitu bagaimana guru biasanya berpikir dan berbuat, selain itu juga kebudayaan masyarakat setempat. Responsif terhadap kebutuhan dimaksudkan kurikulum yang tanggap terhadap perubahan masyarakat akan bisa diterima secara meluas.

Hernawan $^{12}$ mengemukakan lima prinsip dalam pengembangan kurikulum yaitu prinsip relevansi, prinsip fleksibilitas, pinsip kontinuitas, prinsip efisiensi dan prinsip efektivitas. Prinsip relevansi yaitu secara internal kurikulum memiliki relevansi diantara komponen-komponen kurikulum, sedangkan secara eksternal, komponen-komponen tersebut memiliki relevansi dengan tuntutan ilmu pengetahun dan teknologi, tuntutan dan potensi peserta didik serta tuntutan dan kebutuhan perkembangan masyarakat.

Prinsip fleksibilitas yaitu dalam pengembangan kurikulum, hasilnya memiliki sifat luwes, lentur dan fleksibel dalam pelaksanaannya, memungkinkan terjadinya penyesuaian. Prinsip kontinuitas berarti ada kesinambungan dalam kurikulum baik secara vertical maupun horizontal. Kesinambungan ini antar tingkat kelas, antar jenjang pendidikan maupun antara jenjang pendidikan dengan jenis pekerjaan. Prinsip efisiensi adalah mengusahakan agar dalam pengembangan kurikulum dapat mengoptimalkan waktu, biaya dan sumber-sumber lain secara cermat dan tepat. Sedangkan prinsip efektivitas yaitu mengusahakan agar kegiatan pengembangan kurikulum mencapai tujuan baik secara kuantitas maupun kualitas.

11 Ibid, hlm. 128-130

12 A.H. Hernawan, Prinsip-prinsip Pengembangan Kurikulum. Jakarta: Rineka Cipta, 2002 
Tracer Study Jurusan Perbankan Syariah

\section{Desain Penelitian}

Penelitian ini merupakan studi penelusuran (tracer study) yang berupaya melacak kondisi dan kinerja lulusan program studi Perbankan Syariah IAIN Walisongo yang sudah terjun ke masyarakat. Penelusuran dilakukan terhadap alumni yang sudah lulus sekurang-kurangnya dua tahun dari waktu pelaksanaan penelitian, dan pengguna alumni yang merupakan atasan dari alumni Prodi Perbankan Syariah. Pemberlakuan persyaratan waktu kelulusan ini dilakukan karena salah satu informasi yang dilacak adalah rentang waktu untuk mendapatkan pekerjaan setelah lulus.

\section{Populasi dan Sampel}

Populasi penelitian ini adalah seluruh tamatan prodi perbankan syariah sejak pertama kali prodi tersebut menghasilkan lulusan yang tersebar di seluruh wilayah Indonesia. Karena berbagai keterbatasan, antara lain: dana, tenaga, dan teknis pelaksanaan, maka untuk kepentingan penelitian ini hanya diambil sebagian di antara mereka, khususnya lulusan yang berdomisili di wilayah Jawa Tengah. Di samping pembatasan tersebut, untuk mendapatkan informasi sesuai tujuan penelitian, lulusan yang diteliti dibatasi pada lulusan yang sudah tamat dari Program Studi Perbankan Syariah sekurang-kurangnya dua tahun dari waktu pelaksanaan penelitian. Pada penelitian ini sampel diambil secara acak sederhana setelah terlebih dahulu diidentifikasi lulusan yang tamat sekurang-kurangnya dua tahun dari waktu pelaksanaan penelitian.

\section{Metode Pengumpulan Data}

Data yang diperlukan dikumpulkan dengan angket yang dikirimkan langsung ke alamat lulusan dan pengguna lulusan. Alamat lulusan dilacak dengan mencari informasi ke daftar alamat alumni yang diisi pada saat wisuda. Metode yang digunakan adalah on line dan off line. Alumni yang dapat dilacak alamat emailnya akan dikirim kuesioner melalui email (on line), dan dikonfirmasi melalui telepon atau pesan singkat SMS. Untuk metode off line, alumni yang datang langsung diminta untuk mengisi, atau kunjungan langsung ke tempat kerja alumni. 
Setelah mengirimkan kuesioner secara on line ataupun off line, surveior memonitor kemajuan pengisian kuisioner. Alumni yang belum mengisi kuisioner dihubungi kembali melalui telepon dan sms. Proses ini diulang dua kali. Data yang terkumpul akhirnya dianalisis dan disajikan dalam bentuk statistif deskriptif.

\section{Alur Kerja Survei Penelusuran Alumni}

Gambar di bawah ini secara singkat menjelaskan alur kerja survei. Alur kerja survei penelusuran alumni ini secara garis besar dibagi menjadi tiga bagian, yaitu fase persiapan, fase lapangan dan fase paska lapangan.

\section{Gambar 1}

\section{Alur Kerja Survei Penelusuran Alumni}

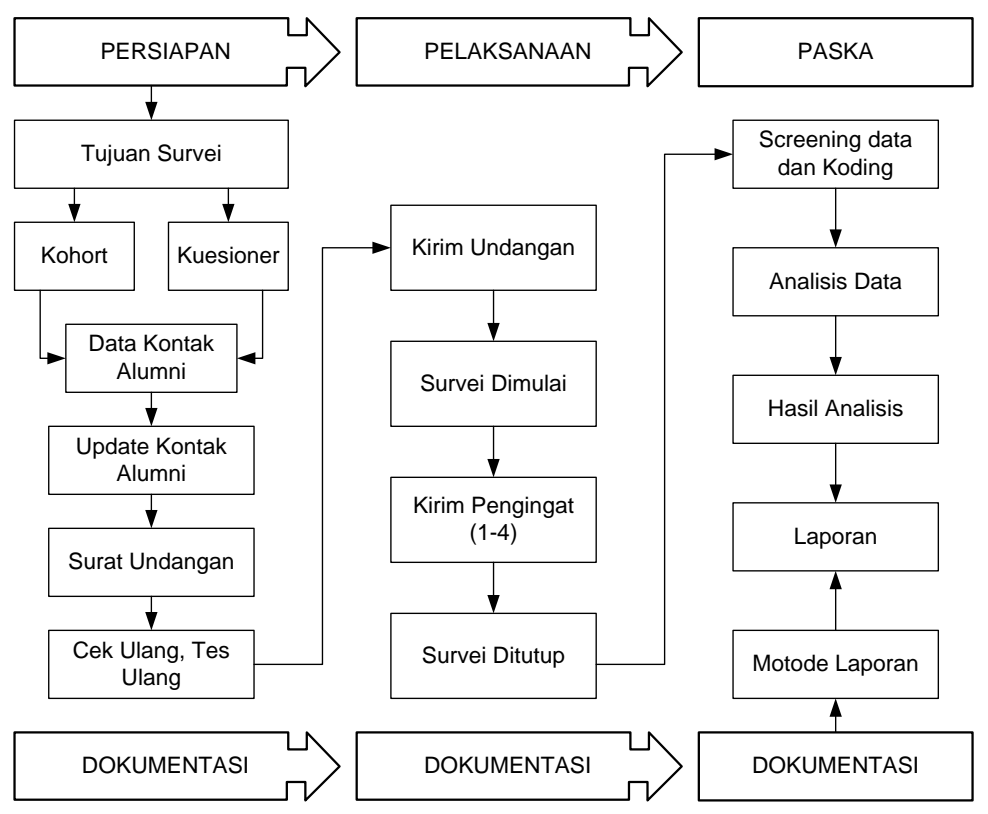

\section{Fase Persiapan}

Fase persiapan dimulai dengan menentukan secara jelas tujuan survei. Menentukan kontrak (construct) yang jelas sangat berperan dalam fase ini. apakah yang menjadi tujuan dari survei secara keseluruhan, dan bagaimana tujuan dari survei tersebut diterjemahkan dalam pertanyaan-pertanyaan dalam 
kuesioner. Tujuan pada tahap ini adalah penyusunan alat ukur yang valid. Pada survei ini, validitas konstrak dipengaruhi oleh operasionalisasi dari elemenelemen dalam kuesioner. Batasan-batasan dari operasionalisasi elemen (definisi operasional) harus jelas. Penentuan tujuan survei penelusuran alumni sangat berhubungan langsung dengan kohort (cohort) dan isi dari kuesioner. Yang dimaksud kohort atau kelompok usia di sini adalah batasan target alumni yang akan disurvei. Misalnya akan melakukan survei yang bertujuan untuk mengevaluasi kurikulum, maka harus dipastikan dulu bahwa target responden adalah alumni yang pada waktu kuliah mendapatkan kurikulum tersebut.

Langkah selanjutnya adalah mendapatkan data kontak alumni yang bisa berupa email, telepon, alamat rumah, dan lain-lain. Data kontak alumni ini sangat penting sebagai sample frame, dimana sample frame merupakan daftar dari populasi yang akan dijadikan dasar proses pengambilan sampel. Misalnya akan dilakukan seurvei pada lulusan tahun 2012, maka harus terdapat daftar elemen yang mewakili seluruh lulusan tahun 2012. Bila daftar kontak belum lengkap, maka perlu dilakukan pembaruan (update). Bila survei dilakukan dengan sistem online, maka alamat email merupakan suatu keharusan sehingga daftar email alumni harus lengkap terlebih dahulu. Proses update kelengkapan data kontak alumni semacam ini biasanya memakan banyak waktu. Sebenarnya hal ini bisa diantisipasi dengan melengkapi data kontak alumni sebelum wisuda. Misalnya dengan mewajibkan calon wisudawan mengisi formulir yang berisi informasi kontak alumni tersebut. Bisa juga ditambahkan data kontak orang tua dari calon wisudawan, sehingga ketika alumni tersebut tidak dapat dilacak, bisa menghubungi orang tua yang bersangkutan.

Bila data kontak alumni telah lengkap, langkah selanjutnya adalah menyiapkan surat undangan, bisa berupa surat yang dikirimkan lewat pos atau dalam bentuk email. Surat undangan harus memotivasi alumni untuk mengisi kuesioner, namun juga tidak boleh bersifat memaksa. Hal yang perlu disertakan dalam surat undangan diantaranya adalah tujuan survei, kerahasiaan data, alamat online kuesioner, alamat website dimana informasi lebih lanjut bisa didapatkan, dan kontak penanggung jawab kuesioner online. Sebelum fase lapangan dimulai, perlu dilakukan pengecekan dan pengetesan ulang, misalnya bila menggunakan kuesioner online, maka perlu dilakukan uji coba, apakah 
kuesioner online identik dengan kuesioner versi cetak, apakah data yang diisi oleh responden terekam dalam basis data atau tidak.

\section{Fase Lapangan}

Fase lapangan dimulai dengan mengirimkan undangan ke alumni untuk mengisi kuesioner. Sebelumnya harus dipastikan terlebih dahulu bahwa kuesioner sudah final. Setelah survei dimulai, maka perlu dikirimka pengingat yang jumlahnya bisa mencapai empat kali dengan jeda setiap dua minggu. Tentu saja ini tergantung jumlah respon yang diterima. Mengirimkan pengingat berdampak cukup signifikan dalam meningkatkan jumlah respon.

\section{Fase Paska Lapangan}

Fase paska lapangan dimulai setelah survei ditutup. Tahap ini identik dengan proses pengolahan data. Pertama kali adalah melakukan pengkodean (koding) dari jawaban teks pertanyaan terbuka. Proses ini menyita cukup banyak waktu sehingga keberadaan pertanyaan terbuka sebaiknya diminimalkan. Setelah proses koding selesai, kemudian masuk ke dalam proses selanjutnya, yaitu analisis data. Analisis menggunakan analisis deskriptif yang hasilnya dirangkum dalam tabel-tabel standar dengan berbagai variabel pemilah (break variable). Variabel standar yang sering digunakan sebagai pemilah diantaranya adalah gender, program studi, dan tingkat pendidikan. Analisis dalam studi ini juga akan menggunakan analisis korelasi. Tahap selanjutnya adalah menyusun laporan akhir yang datanya diambil dari hasil analisis.

\section{Dokumentasi}

Proses dokumentasi dalam setiap tahap pelaksanaan survei sangat penting untuk dilakukan. Dokumentasi ini nantinya juga akan sangat berguna dalam membuat laporan metode. Laporan metode ini berisi proses-proses apa saja yang kita lakukan, baik dalam proses persiapan, pelaksanaan, maupun analisis data. Dokumentasi pada proses persiapan bisa berisi informasi yang berhubungan dengan isi kuesioner. Dokumentasi tentang dasar konstrak dari 
Tracer Study Jurusan Perbankan Syariah

pertanyaan-pertanyaan dalam kuesioner. Logika pemilihan suatu pertanyaan dibanding pertanyaan lainnya, alasan kategorisasi pilihan jawaban pertanyaan tertentu, dan sebagainya. Dokumentasi pada proses persiapan bisa pula berisi informasi yang berhubungan dengan prosedur pelaksanaan, misalnya: jumlah alumni yang menjadi target survei, mengenai kelengkapan kontak alamat alumni, dan mengenai kendala-kendala yang dihadapi.

Dokumentasi pada proses pelaksanaan misalnya berupa catatan jumlah alumni yang diundang, jumlah alumni yang alamat kontaknya salah (missal: email tertolak), berapa kali dan kapan pengingat dikirimkan, dan kapan survei dimulai serta ditutup. Sementara itu, dokumentasi pada proses fase paska lapangan biasanya berisi langkah-langkah dalam modifikasi data dan sebagainya.

\section{Tahapan Pelaksanaan}

Beberapa tahapan penelusuran alumni dilakukan secara paralel, misalnya pengembangan database alumni berlangsung bersamaan dengan pengembangan kuisioner (Gambar 3.2). Database alumni memuat nama, NIM, alamat email, nomor HP/telepon dan alamat rumah. Pengembangan kuisioner dilakukan dengan melibatkan para pimpinan fakultas untuk mengakomodir kebutuhan spesifik fakultas. Setelah instrumen survei selesai dibuat, maka informasi pelaksanaan tracer study disampaikan dengan berbagai mekanisme. Karena keterbatasan waktu dan mempertimbangkan efektifitas pelaksanaan, maka hanya alumni yang memiliki nomor HP/telepon yang dihubungi. Setelah menghubungi alumni, surveior memonitor kemajuan pengisian kuisioner. Alumni yang belum mengisi kuisioner dihubungi kembali melalui telepon dan sms. Proses ini diulang dua kali. Data yang terkumpul akhirnya dianalisis dan disajikan dalam bentuk statistif deskriptif.

\section{Gambar 2}

Model Pelaksanaan Survei Penelusuran Alumni

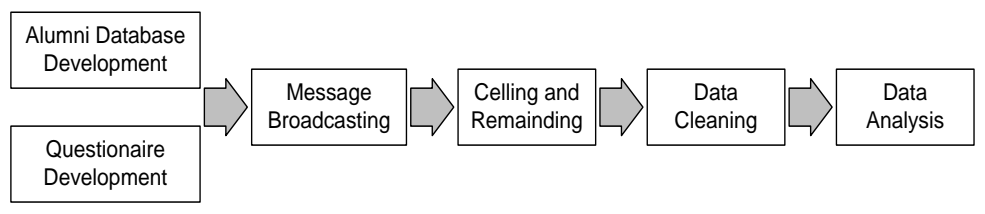


Pengembangan kuisioner tracer study dilakukan melalui beberapa tahap, yaitu:

1. Penyusunan draft kuisioner oleh tim tracer study.

2. Penyempurnaan kuisioner.

3. Finalisasi kuesioner oleh tim tracer study, berdasarkan umpan balik yang diberikan.

Kuesioner survei dirancang dengan mengkombinasikan (1) Kusioner minimum tracer study I-MHERE Dikti (2) Kuisioner Indotrace dan (3) Kebutuhan Program Studi Perbankan Syariah. Kuisioner lengkap dapat dilihat pada Lampiran 1. Pertanyaan-pertanyaan pada kuisioner dikelompokkan menjadi lima bagian, terdiri dari 38 pertanyaan mencakup:

1. Karakteristik sosio-biografi (7 pertanyaan)

2. Pencarian kerja dan transisi ke dunia kerja (4 pertanyaan)

3. Pekerjaan dan kompetensi (27 pertanyaan)

Pertanyaan-pertanyaan pada bagian 3-5 sebagian besar merupakan pertanyaan yang mengukur persepsi responden. Sosialisasi informasi tentang pelaksanaan Tracer study dilakukan melalui beberapa mekanisme, sosialisasi kepada seluruh dosen melalui mailing list agar menyebarkan informasi kepada seluruh alumni yang dikenal melalui jaringan sosial online (misalnya facebook, yahoo groups dan sebagainya).

\section{Gambar 3}

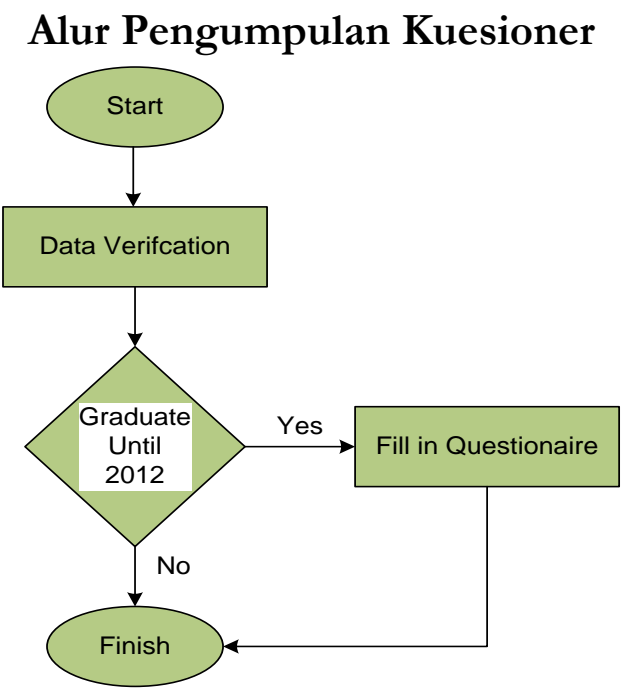

Volume VI/Edisi 2/Oktober 2015 
Tracer Study Jurusan Perbankan Syariah

\section{Deskripsi Objek Penelitian}

Responden dalam penelitian ini adalah mahasiswa Jurusan Perbankan Syariah IAIN Walisongo Semarang. Data penelitian dikumpulkan dengan mengirimkan secara langsung 200 kuesioner pada alumni program studi D3 Perbankan Syari'ah IAIN Walisongo Semarang, dengan mengantarkan kepada seluruh responden yang menjadi objek penelitian melalui surat (mail survey). Distribusi kuesioner dimulai pada tanggal 3 Juni 2014. Pengumpulan kembali dilakukan 1 bulan setelah kuesioner diantar, yaitu pada tanggal 8 Juli 2014. Dari 83 responden yang berpartisipasi dalam penelitian ini 6 diantaranya tidak dapat diikutsertakan karena pengisian yang tidak lengkap, sehingga jumlah kuesioner yang layak dianalisis sebanyak 77 kuesioner. Tingkat respon rate sebesar 41,5 persen adalah tinggi, karena metode mail survey kemungkinan dikembalikan adalah sebesar $15 \%$. Selain itu, jangka waktu survey yang tidak begitu panjang juga mengakibatkan rendahnya respon rate dalam studi ini.

Ringkasan pengiriman dan pengembalian kuesioner dalam penelitian ini ditunjukkan dalam Tabel 1

Tabel 1

Rincian Pengiriman Dan Pengembalian Kuisioner

\begin{tabular}{|l|l|}
\hline \hline Keterangan : & $\begin{array}{l}\text { Jumlah } \\
\text { Kuesioner }\end{array}$ \\
\hline \hline Total Kuisioner yang didistribusikan & 200 \\
\hline $\begin{array}{l}\text { Jumlah Kuesioner yang tidak } \\
\text { kembali }\end{array}$ & $(117)$ \\
$\begin{array}{l}\text { Jumlah Kuisioner yang kembali } \\
\text { Jumlah Kuisioner yang tidak dapat } \\
\text { digunakan }\end{array}$ & 83 \\
$\begin{array}{l}\text { Jumlah Kuisioner yang dapat } \\
\text { digunakan }\end{array}$ & 77 \\
\hline $\begin{array}{l}\text { Tingkat pengembalian (Respon rate) } 83 / 200 \times 100 \%= \\
41,5 \%\end{array}$ \\
$\begin{array}{l}\text { Tingkat pengembalian yang digunakan (Usable respon } \\
\text { rate) } 77 / 83 \times 100 \%=89,76 \%\end{array}$ \\
\hline \hline
\end{tabular}

Sumber: Data primer diolah, 2014. 


\section{Gambaran Umum dan Karier Responden}

Responden dalam penelitian ini adalah alumni program studi D3 Perbankan Syari'ah IAIN Walisongo yang telah lulus sekurang-kurangnya 2 tahun dari waktu pelaksanaan. Hal ini dilakukan karena salah satu informasi yang dilacak adalah rentang waktu untuk mendapatkan pekerjaan setelah lulus. Keseluruhan jumlah responden yang terpilih sejumlah 77 orang. Untuk mengetahui gambaran umum tentang identitas responden dapat diketahui dari seluruh jawaban kuesioner yang disebarkan pada responden jawaban tersebut digolongkan menjadi tiga (3) keadaan responden yaitu jenis kelamin, usia, tahun kelulusan.

\subsection{Komposisi Jenis Kelamin Responden}

Analisis terhadap responden menurut jenis kelamin dilakukan untuk mengetahui proporsi jenis kelamin responden. Berikut ini adalah komposisi jenis kelamin responden yang disajikan dalam Gambar di bawah ini.

\section{Gambar 4}

Distribusi Responden Berdasarkan Jenis Kelamin

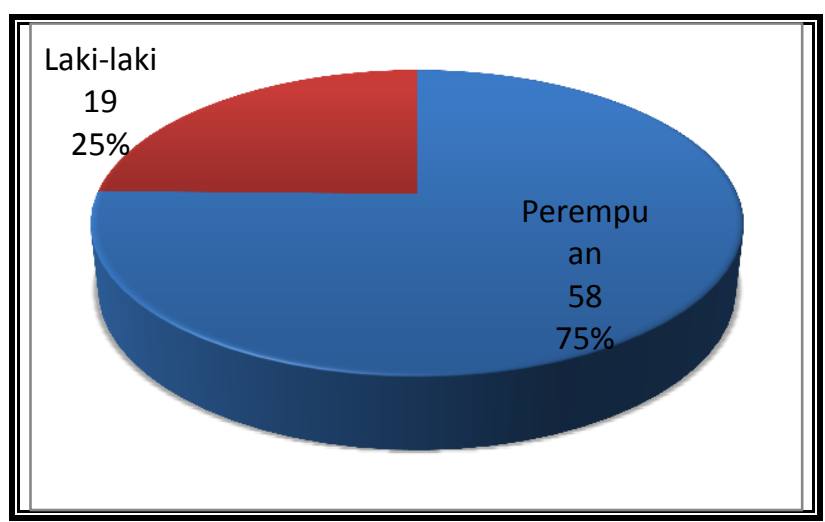

Sumber: Data primer diolah, 2014.

Berdasar hasil distribusi responden menurut jenis kelamin, menunjukkan bahwa mayoritas responden dalam penelitian ini adalah perempuan, yaitu sebanyak 58 orang $(75 \%)$. Sedangkan responden dengan jenis kelamin laki-laki adalah sebanyak 19 orang (25\%). 
Tracer Study Jurusan Perbankan Syariah

\subsection{Komposisi Usia Responden}

Usia responden merupakan salah satu faktor yang perlu diperhatikan, karena kebijakan dalam pengambilan keputusan untuk melakukan penilaian dipengaruhi oleh usia seseorang. Adapun komposisi responden berdasarkan tingkat usia responden tersaji dalam Gambar 4.2.

Gambar 5

Frekuensi Responden Berdasarkan Usia

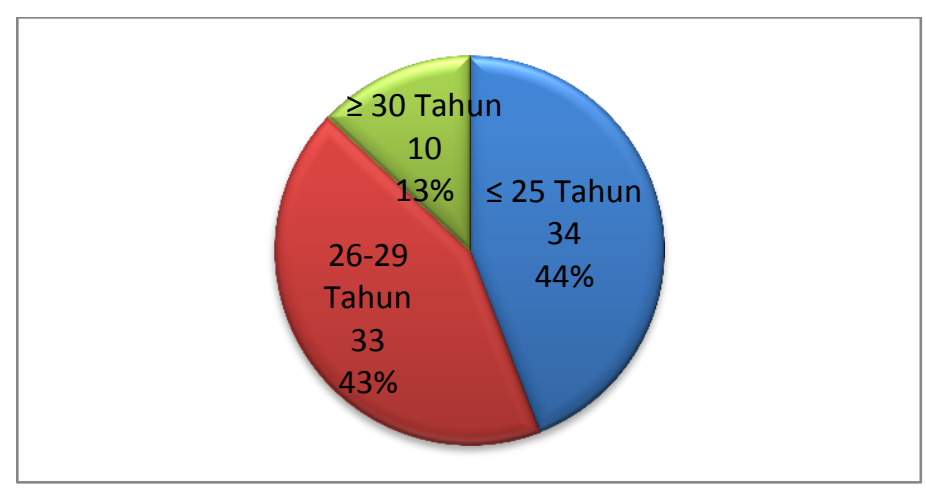

Sumber: Data primer diolah, 2014.

Berdasarkan gambar di atas mengenai komposisi tingkat usia responden menunjukkan bahwa sebagian besar responden adalah responden yang berusia kurang dari 25 tahun sebanyak 34 orang (44\%), sedangkan responden paling sedikit adalah responden dengan usia lebih dari 30 tahun sebanyak 10 orang (13\%). Sementara itu, responden yang berusia kurang antara 26 sampai dengan 29 Tahun sebanyak 33 orang (43\%). Hal ini terjadi karena usia bagi seorang mahasiswa fresh graduate pada umumnya adalah berkisar kurang dari 25 tahun.

\subsection{Tahun Kelulusan Responden}

Latar tahun kelulusan akan mempengaruhi lama masa kerja serta kemungkinan melakukan perpindahan kerja. Hasil survey menunjukkan berbagai tahun kelulusan responden, yaitu seperti yang ditunjukkan dalam Gambar 4.3. 
Gambar 6

Frekuensi Berdasarkan Pendidikan Terakhir Responden

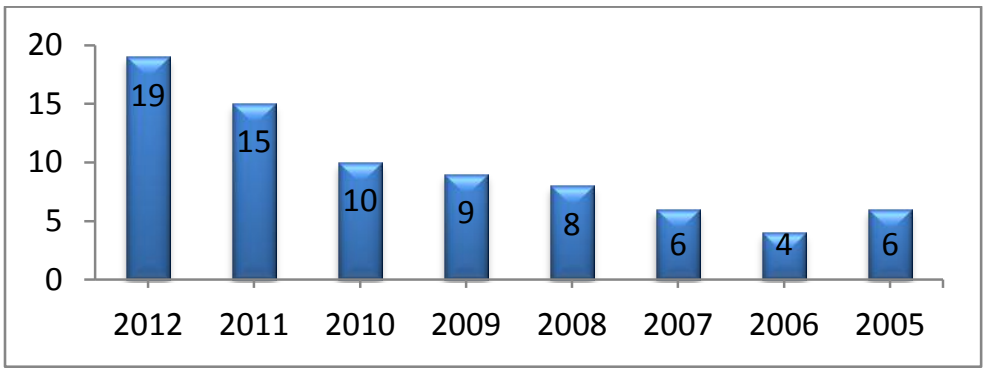

Sumber: Data primer diolah, 2014.

Berdasarkan gambar di atas dapat diketahui bahwa tahun kelulusan responden terbesar adalah Tahun 2012 sebanyak 19 orang diikuti dengan Tahun 2011 sebanyak 15 orang. Tahun kelulusan yang paling sedikit adalah Tahun 2006 sebanyak 4 orang.

\section{Masa Tunggu Sebelum Mendapatkan Pekerjaan}

\subsection{Kegiatan Selama Masa Tunggu}

Kegiatan selama masa tunggu adalah kegiatan responden setelah lulus sampai dengan sebelum mendapatkan pekerjaan. Hasil survey menunjukkan berbagai kegiatan selama masa tunggu responden, yaitu seperti yang ditunjukkan dalam Gambar di bawah ini:

Gambar 7

Kegiatan Selama Masa Tunggu

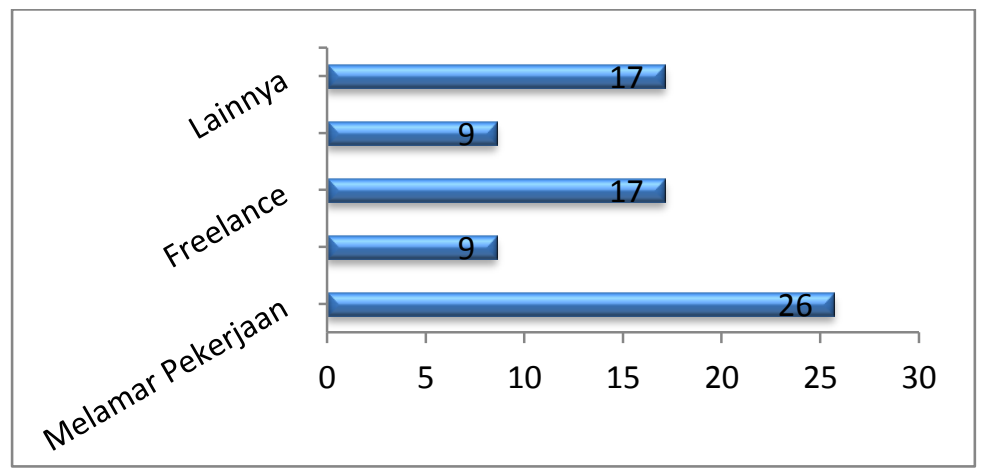

Sumber: Data primer diolah, 2014. 
Tracer Study Jurusan Perbankan Syariah

Berdasarkan gambar di atas dapat diketahui bahwa kebanyakan responden mengisi waktu setelah lulus dengan melamar pekerjaa sebanyak 26 orang. Sedangkan yang melakukan pekerjaan bebas (freelance) adalah sebanyak 17 orang, dan yang melakukan kegiatan dengan kursus sebanyak 9 orang. Sementara itu, terdapat beberapa responden yang melakukan pekerjaan wiraswasta dalam masa tunggunya, yaitu sebanyak 9 orang, dan yang tidak diketahui aktifitas kegiatannya selama masa tunggu adalah sebanyak 17 orang.

\subsection{Kesulitan Dalam Mencari Pekerjaan}

Terkiat dengan masalah masa tunggu pekerjaan, menunjukkan adanya beberapa kesulitan responden dalam mencari pekerjaan. Hasil survey menunjukkan berbagai masalah kesulitan responden dalam mencari pekerjaan, yaitu seperti yang ditunjukkan dalam Gambar di bawah ini:

\section{Gambar 8}

Alasan Kesulitan Mencari Pekerjaan

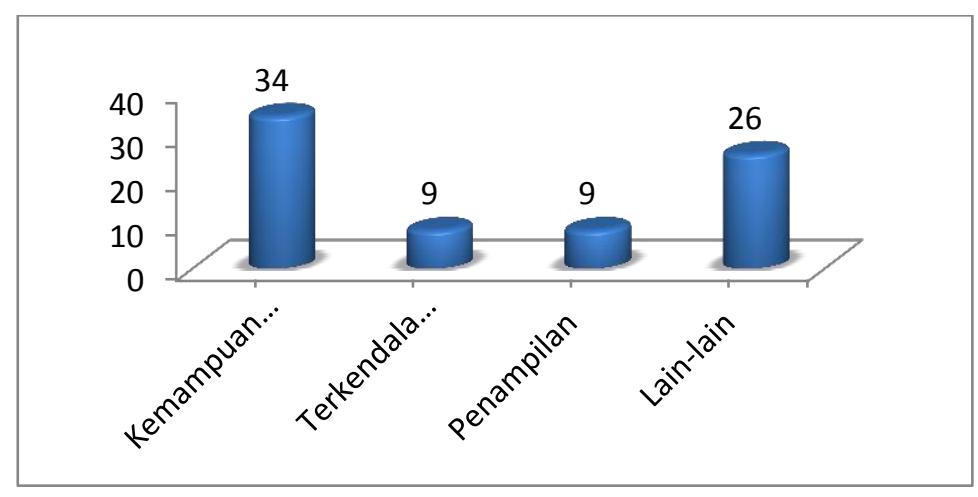

Sumber: Data primer diolah, 2014.

Berdasarkan gambar di atas dapat diketahui bahwa kebanyakan responden mengalami kesulitan dalam bidang kemampuan komunikasi sebanyak 34 orang. Kemampuan komunikasi terkait dengan penguasaan bahasa asing serta gaya berkomunikasi. Sedangkan kesulitan lain yang berkaitan dengan penampilan dan masalah administrasi, dirasakan oleh 18 responden, masing-masing sebanyak 9 orang. Sementara itu kesulitan lain-lain berupa akses informasi, aspek non teknis, dan sebagainya dirasakan oleh 26 responden. 


\section{Tempat Kerja Pertama}

2.6. Cara Mendapatkan Informasi Pekerjaan

Cara mendapatkan informasi merupakan sumber informasi bagi resonden dalam rangka mendapatkan pekerjaan. Hasil survey menunjukkan berbagai sumber informasi dalam rangka mendapatkan pekerjaan, yaitu seperti yang ditunjukkan dalam Gambar di bawah ini:

Gambar 9

Informasi Dalam Mendapatkan Pekerjaan

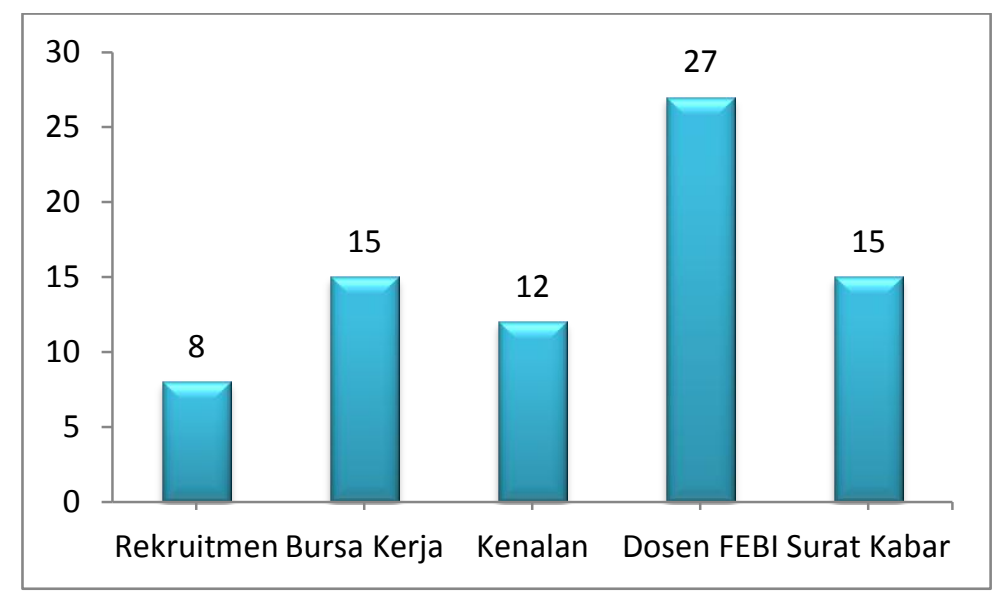

Sumber: Data primer diolah, 2014.

Berdasarkan gambar di atas dapat diketahui bahwa kebanyakan responden memperoleh informasi melalui dosen dan karyawan FEBI, yaitu sebanyak 27 orang. Sarana informasi lainnya adalah melalui Bursa Kerja dan Media Cetak sebanyak 15 responden, sedangkan yang paling sedikit adalah melalui rekrutmen sebanyak 8 orang.

\subsection{Waktu Mendapatkan Pekerjaan}

Waktu mendapatkan pekerjaan merupakan waktu yang dibutuhkan responden untuk mendapatkan pekerjaan terhitung sejak wisuda. Hasil survey menunjukkan berbagai waktu dalam mendapatkan pekerjaan, yaitu seperti yang ditunjukkan dalam Gambar di bawah ini: 
Tracer Study Jurusan Perbankan Syariah

Gambar 9

Waktu yang Dibutuhkan Untuk Memperoleh Pekerjaan

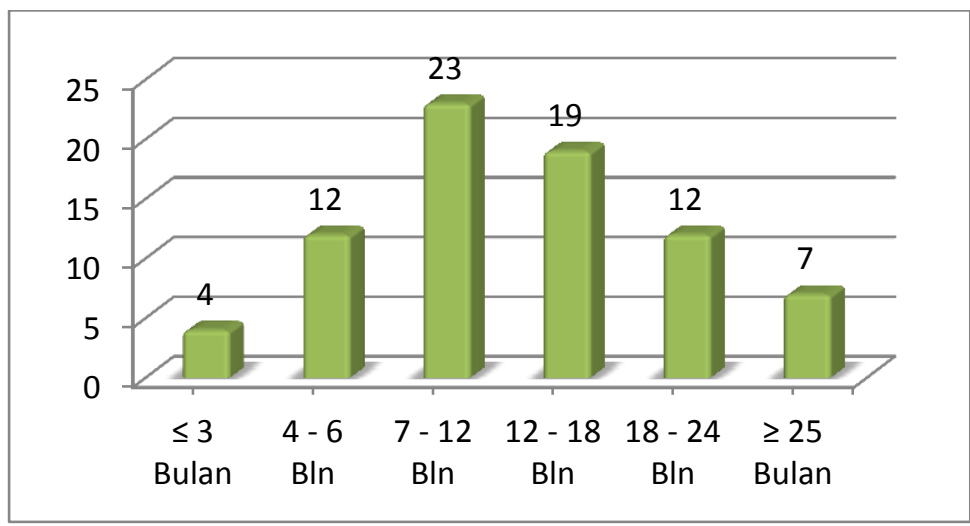

Sumber: Data primer diolah, 2014.

Berdasarkan gambar di atas dapat diketahui bahwa kebanyakan responden mempunyai jangka waktu yang cukup lama dalam mendapatkan pekerjaan. Mayoritas responden mempunyai jangka waktu sebesar 7-12 bulan, sebanyak 23 orang, diikuti dengan jangka 12-18 bulan sebanyak 19 orang. Sementara itu, waktu paling sedikit (kurang dari 3 bulan) bagi responden untuk mendapatkan pekerjaan hanya terdapat 4 orang, dan 12 orang mempunyai jangka waktu selama 4 sampai dengan 6 bulan. Hal ini bisa terjadi karena kemungkinan adanya waktu kelulusan yang kurang sesuai dengan masa penerimaan kerja, yang berdampak pada rata-rata jangka waktu yang lama dalam mendapatkan pekerjaan.

\subsection{Kesesuaian Pekerjaan dengan Keahlian}

Kesesuaian pekerjaan merupakan kesesuaian antara pekerjaan resonden dengan bidang keahlian yang didapatkan selama masa studi. Hasil survey menunjukkan kesesuaian pekerjaan dengan bidang keahlian responden, yaitu seperti yang ditunjukkan dalam Gambar di bawah ini: 
Gambar 10

Kesesuaian Antara Pekerjaan dengan Bidang Keahlian

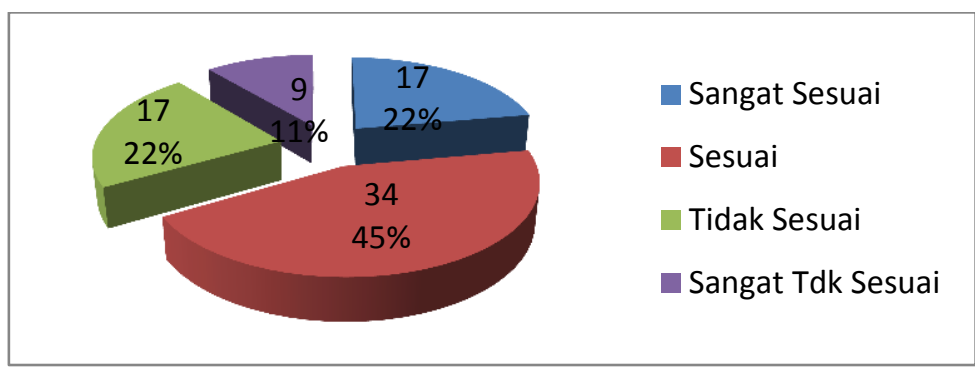

Sumber: Data primer diolah, 2014.

Berdasarkan gambar di atas dapat diketahui bahwa kebanyakan responden merasakan adanya kesesuaian antara bidang keahilan yang mendasarkan pada latar belakang pendidikan dengan pekerjaan. Mayoritas responden merasakan adanya kesesuaian antara pekerjaan dan bidang keahlian yaitu sebanyak 34 orang (45\%). Sedangkan responden yang merasakan adanya ketidak sesuaian hanya dialami oleh 9 orang (11\%). Sementara itu, pilihan ekstrim seperti sangat sesuai dan sangat tida sesuai dirasakan oleh responden dengan proporsi yang sama, yaitu masing-masing 17 orang (22\%). Hal ini terjadi karena kemungkinan berkaitan dengan waktu kelulusan panjang, yang diakibatkan oleh responden menunggu adanya pekerjaan yang sesuai dengan bidang keahliannya. Sehingga dengan demikian berdampak pada rata-rata kesesuaian pekerjaan dengan bidang keahlian adalah sesuai.

\subsection{Kemampuan Non Akademis yang dibutuhkan fresh graduate}

Kemampuan non akademis merupakan kemampuan yang seharusnya dimiliki oleh responden terkait dengan kemampuan di luar pendidikan dalam rangka mendapatkan pekerjaan. Hasil survey menunjukkan berbagai kemampuan non akademis yang seharusnya dimiliki oleh responden dalam rangka mendapatkan pekerjaan, yaitu seperti yang ditunjukkan dalam Gambar di bawah ini: 
Tracer Study Jurusan Perbankan Syariah

\section{Gambar 11}

Kebutuhan Kemampuan Non Akademis Terkait Pekerjaan

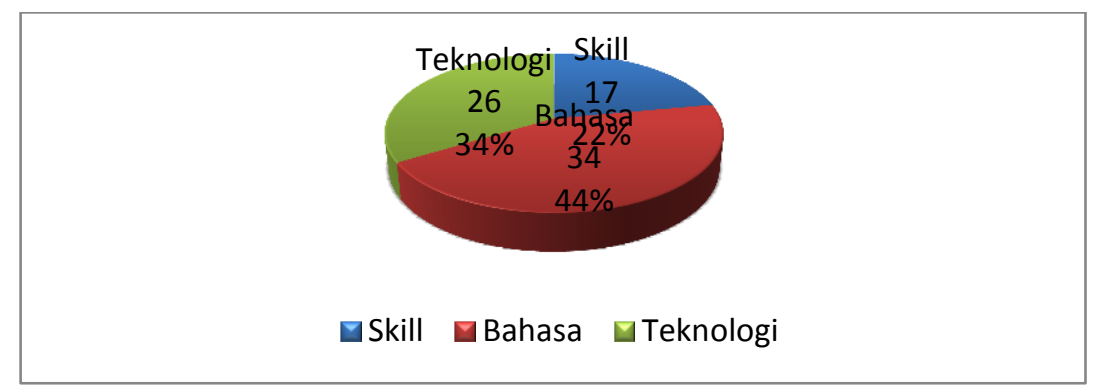

Sumber: Data primer diolah, 2014.

Berdasarkan gambar di atas dapat diketahui bahwa kebanyakan responden merasakan adanya kebutuhan akan kemampuan bahasa asing yang seharusnya dimiliki oleh lulusan FEBI. Mayoritas responden merasakan adanya kebutuhan akan kemampuan bahasa yaitu sebanyak 34 orang (44\%). Sedangkan responden yang merasakan kebutuhan akan kemampuan di bidang teknologi informasi dialami oleh 26 orang (34\%). Sementara itu, kemampuan skill atau ketrampilan dirasakan oleh minimal responden, yaitu sebanyak 17 orang $(22 \%)$. Dengan demikian dapat disimpulkan bahwa selain kebutuhan akan kemampuan bidang akademis, selayaknya mahasiswa juga dibekali oleh kemampuan non akademis, seperti kemampuan bahasa, kemampuan skill serta kemampuan penggunaan teknologi informasi.

\subsection{Tingkat Persaingan Job Seeker}

Tingkat persaingan merupakan persaingan yang dialami oleh responden dalam rangka mendapatkan pekerjaan. Hasil survey menunjukkan penilaian responden terkait adanya persaingan dalam rangka mendapatkan pekerjaan, yaitu seperti yang ditunjukkan dalam Gambar 4.10. 


\section{Gambar 12}

Tingkat Persaingan dalam Mendapatkan Pekerjaan

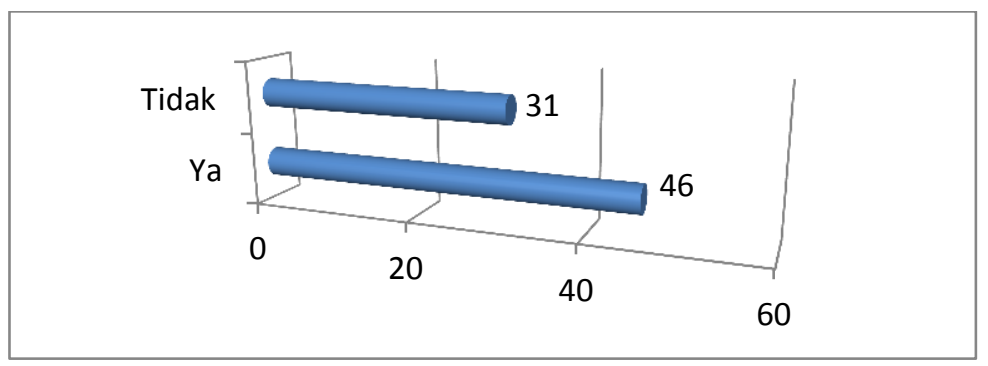

Sumber: Data primer diolah, 2014.

Berdasarkan gambar di atas dapat diketahui bahwa kebanyakan responden tidak mengalami adanya persaingan dalam rangka mendapatkan pekerjaan. Mayoritas responden merasakan tidak mengalami persaingan sebanyak 46 orang, sedangkan responden yang mengalami adanya persaingan dialami oleh sebanyak 26 responden. Hal ini terjadi karena responden dalam survey ini adalah alumni mahasiswa perbankan syariah, dimana lembaga pendidikan tinggi yang menyelenggarakan jurusan perbankan syariah masih sedikit, yang pada akhirnya akan berdampak pada sedikitnya persaingan dalam rangka mendapatkan pekerjaan. Oleh karena itu dapat disimpulkan bahwa jurusan perbankan syariah masih sangat prospektif karena masih minimnya lulusan dan masih sedikitnya lembaga pendidikan tinggi yang membuka jurusan perbankan syariah.

Namun demikian, walaupun kecilnya tingkat persaingan, terdapat juga beberapa responden minoritas yang mengalami persaingan. Persaingan yang dirasakan oleh responden adalah pada umumnya persaingan dengan lulusan Politeknik Negeri Semarang, Undip, Unnes, STAIN Salatiga, Unissula, UKSW, APMB Solo, dan UMS Surakarta.

\section{Instansi}

Instansi merupakan instansi tempat kerja resonden. Hasil survey menunjukkan bermacan instansi responden, yaitu seperti yang ditunjukkan dalam Gambar di bawah ini: 
Tracer Study Jurusan Perbankan Syariah

Gambar 13

Instansi Tempat Kerja Responden

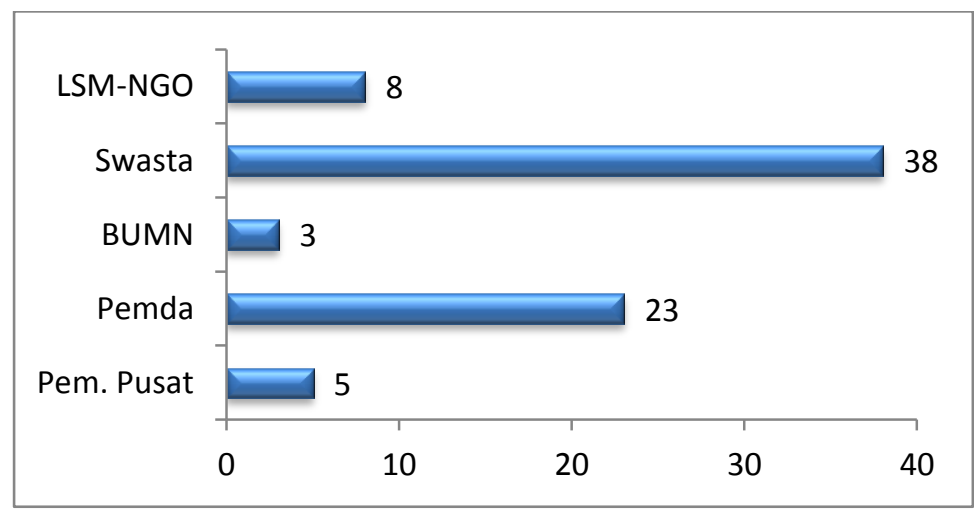

Sumber: Data primer diolah, 2014.

Berdasarkan Gambar di atas dapat diketahui bahwa kebanyakan responden bekerja pada instansi swasta sebanyak 38 orang. Sementara responden terkecil adalah bekerja pada instansi BUMN sebanyak 3 orang.

\section{Pindah Kerja}

Pindah kerja adalah kondisi dimana responden telah melakukan pindah kerja dari pekerjaan yang pertama. Hasil survey menunjukkan kondisi pindah kerja, yaitu seperti yang ditunjukkan dalam Gambar di bawah ini:

Gambar 14

Responden Pindah Kerja 
Berdasarkan Gambar di atas dapat diketahui bahwa kebanyakan responden bekerja pada instansi swasta sebanyak 38 orang. Sementara responden terkecil adalah bekerja pada instansi BUMN sebanyak 3 orang.

\subsection{Jenis Pekerjaan Antara Pekerjaan Pertama dan Pekerjaan Saat Ini}

Jenis pekerjaan pertama dan saat ini menunjukkan apakah jenis pekerjaan yang sekarang dengan pekerjaan pertama adalah berbeda, atau dengan kata lain responden pernah melakukan pindah instansi kerja. Hasil survey mengenai jenis pekerjaan pertama dan saat ini yaitu seperti yang ditunjukkan dalam Gambar di bawah ini:

\section{Gambar 15}

Jenis Pekerjaan Pertama dan Saat Ini

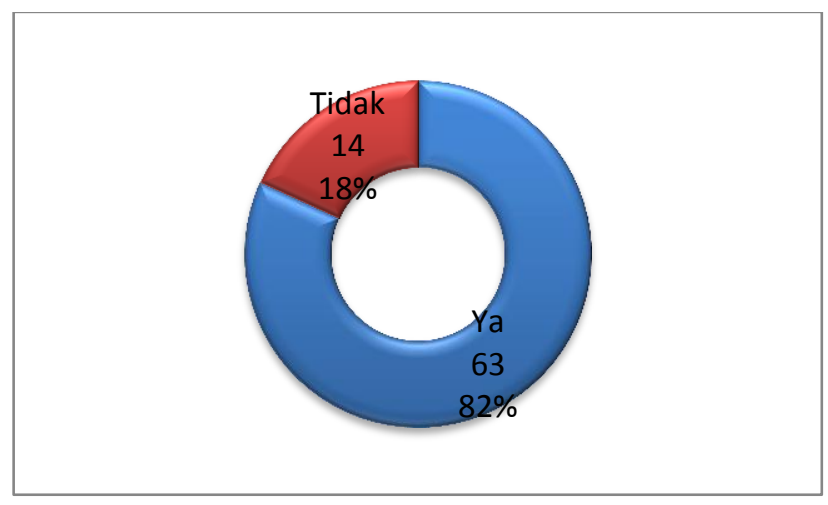

Sumber: Data primer diolah, 2014.

Berdasarkan Gambar di atas dapat diketahui bahwa kebanyakan responden mempunyai jenis pekerjaan yang sama antara yang pertama dan yang sekarang, atau dengan kata lain responden belum pernah melakukan pindah kerja. Mayoritas responden menjawab bahwa mereka belum pernah melakukan pindah perkejaan sebanyak 63 orang (82\%), sedangkan responden yang telah pindah bekerja adalah sebanyak 14 orang (18\%).

Sedangkan bagi responden yang telah pindah bekerja, terdapat beberapa alasan yang mendasarinya. Adapun alasan yang membuat responden berpindah dari tempat kerja pertama ke tempat kerja sekarang disajikan dalam Gambar di bawah ini: 
Tracer Study Jurusan Perbankan Syariah

Gambar 16

Alasan Pindah Tempat Kerja

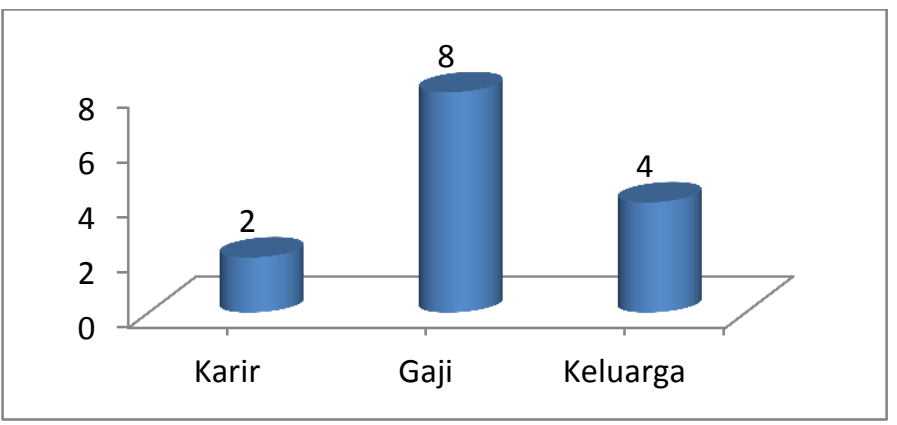

Sumber: Data primer diolah, 2014.

Berdasarkan Gambar di atas, dari sebanyak 14 responden yang melakukan pindah tempat kerja dapat diketahui bahwa kebanyakan responden mempunyai alasan karena faktor gaji, yaitu sebanyak 8 orang. Sementara reponden yang beralasan karena faktor keluarga adalah sebanyak 8 orang, dan responden yang mempunyai alasan karena faktro karir sebanyak 2 orang.

Dengan demikian dapat diambil kesimpulan sementara bahwa dilihat dari aspek gaji, rata-rata responden tidak mempermasalahkan pada aspek gaji yang diterima, hanya sebanyak 8 orang dari keseluruhan responden yang mempermasalahkan faktor gaji.

\subsection{Besar Gaji}

Terkait dengan alasan utama responden melakukan pindah tempat kerja, dimana mayoritas responden yang pindah tempat kerja adalah alas an faktor gaji, maka selanjutnya akan dilakukan survey atas pendapatan/gaji yang diterima oleh responden. Hasil survey menunjukkan beberapa pengelompokan besaran gaji responden, yaitu seperti yang ditunjukkan dalam Gambar di bawah ini: 
Gambar 17

Gaji Responden

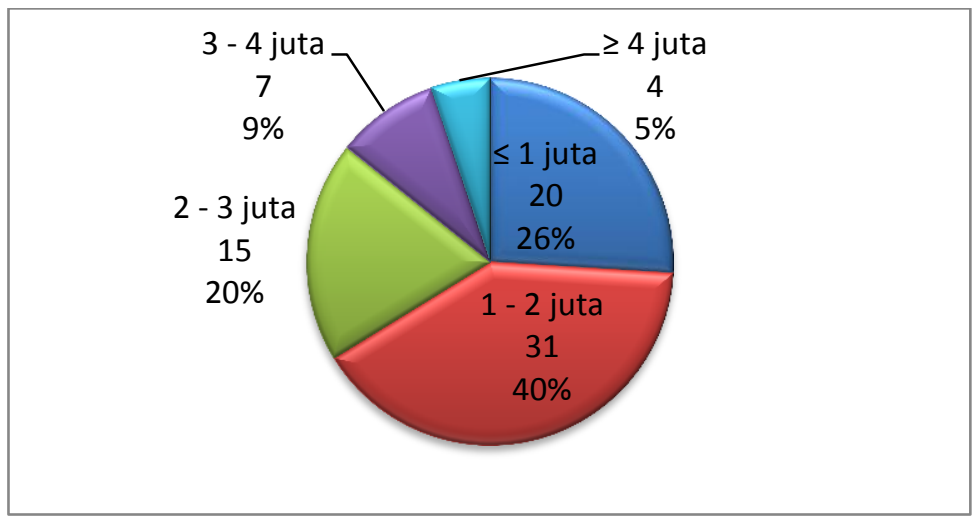

Sumber: Data primer diolah, 2014.

Gambar di atas menunjukkan bahwa rata-rata gaji yang diterima oleh responden adalah sudah diatas upah minimum. Dari sebanyak 77 responden ternyata mayoritas gaji yang diterima oleh mereka adalah berkisar antara 1 hingga 2 juta rupiah, yaitu sebanyak 31 orang (40\%). Sementara responden yang mempunyai pendapatan lebih besar dari 4 juta rupiah per bulan masih sangat sedikit, yaitu sebanyak 4 orang (5\%). Pada beberapa responden masih terdapat responden yang mendapatkan gaji di bawah 1 juta rupiah, yaitu sebanyak 26 orang. Hal ini terjadi karena kemungkinan mereka bekerja di kabupaten luar kota, dimana upah minimum masih di bawah 1 juta rupiah.

\subsection{Kesesuaian Level Pekerjaan dengan Pendidikan}

Kesesuaian level perkejaan merupakan kesesuaian antara tanggung jawab dalam pekerjaan dengan tingkat pendidikan yang diterima selama mengikuti kuliah. Hasil survey menunjukkan level pekerjaan dengan pendidikan, yaitu seperti yang ditunjukkan dalam Gambar di bawah ini: 
Tracer Study Jurusan Perbankan Syariah

Gambar 18

Kesesuaian Level Pekerjaan dan Pendidikan
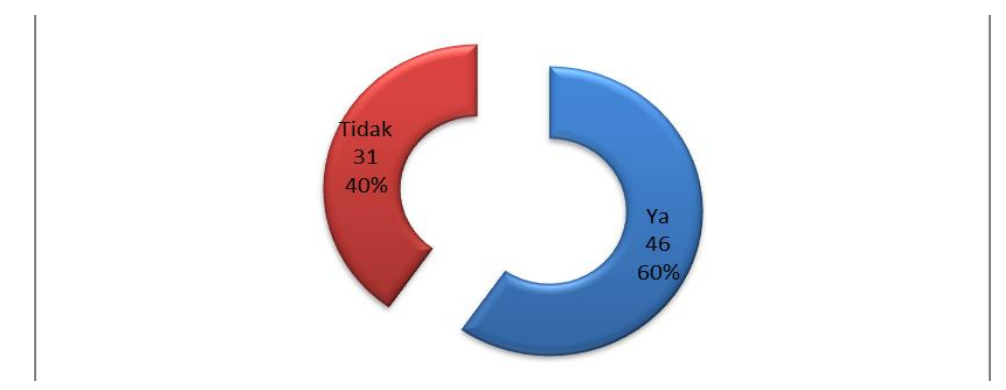

Sumber: Data primer diolah, 2014.

Gambar di atas menunjukkan bahwa rata-rata gaji yang diterima oleh responden adalah sudah diatas upah minimum. Dari sebanyak 77 responden ternyata mayoritas gaji yang diterima oleh mereka adalah berkisar antara 1 hingga 2 juta rupiah, yaitu sebanyak 31 orang (40\%). Sementara responden yang mempunyai pendapatan lebih besar dari 4 juta rupiah per bulan masih sangat sedikit, yaitu sebanyak 4 orang $(5 \%)$. Pada beberapa responden masih terdapat responden yang mendapatkan gaji di bawah 1 juta rupiah, yaitu sebanyak 26 orang. Hal ini terjadi karena kemungkinan mereka bekerja di kabupaten luar kota, dimana upah minimum masih di bawah 1 juta rupiah.

\section{Kebutuhan Promosi Tenaga Kerja}

2.14. Tambahan Pengetahuan

Tambahan pengetahuan merupakan keinginan responden untuk mendapatkan tambahan pengetahuan dalam rangka meningkatkan karir. Hasil survey menunjukkan frekuensi responden dalam rangka atas keinginan untuk mendapat tambahan pengetahuan, yaitu seperti yang ditunjukkan dalam Gambar di bawah ini: 
Gambar 19

Keinginan Responden Untuk Mendapatkan Tambahan Pengetahuan

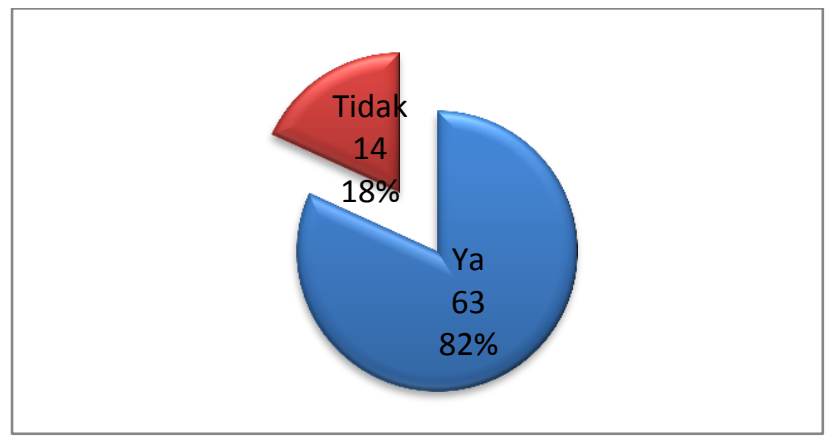

Sumber: Data primer diolah, 2014.

Gambar di atas menunjukkan bahwa rata-rata responden menginginkan untuk mendapat tambahan pengetahuan dalam rangka meningkatkan karir, yaitu sebanyak 63 orang (82\%). Sementara yang sudah merasa cukup dengan pengetahuan mereka dan tidak merasa membutuhkan tambahan pengetahuan adalah sebanyak 14 orang (18\%). Dengan kondisi ini maka menjadi tugas lembaga untuk memenuhi kebutuhan riil mereka dalam lapangan kerja. Adapun persepsi responden dalam hal tambahan pengetahuan yang mereka butuhkan dalam meningkatkan karir adalah pengetahuan mengenai akuntansi konvensional, seperti akuntansi keuangan (intermediate accounting), akuntansi sektor publik/pemerintahan (public sector accounting), pemeriksaan akuntansi (auditing), serta perpajakan. Selanjutnya tambahan pengetahuan lainnya seperti lembaga keuangan syariah, akuntansi perbankan syariah, komunikasi bisnis, pengetahuan bahasa asing serta kewirausahaan.

\subsection{Hambatan Karir}

Hambatan karir merupakan kondisi dimana responden mengalami hambatan karir yang diakibatkan oleh ilmu yang diperoleh selama masa studi tidak sesuai dengan bidang pekerjaan saat ini. Hasil survey terkait hambatan karir seperti yang ditunjukkan dalam Gambar 4.18. 
Tracer Study Jurusan Perbankan Syariah

Gambar 20

Hambatan Karir Terkait Ilmu Selama Masa Studi

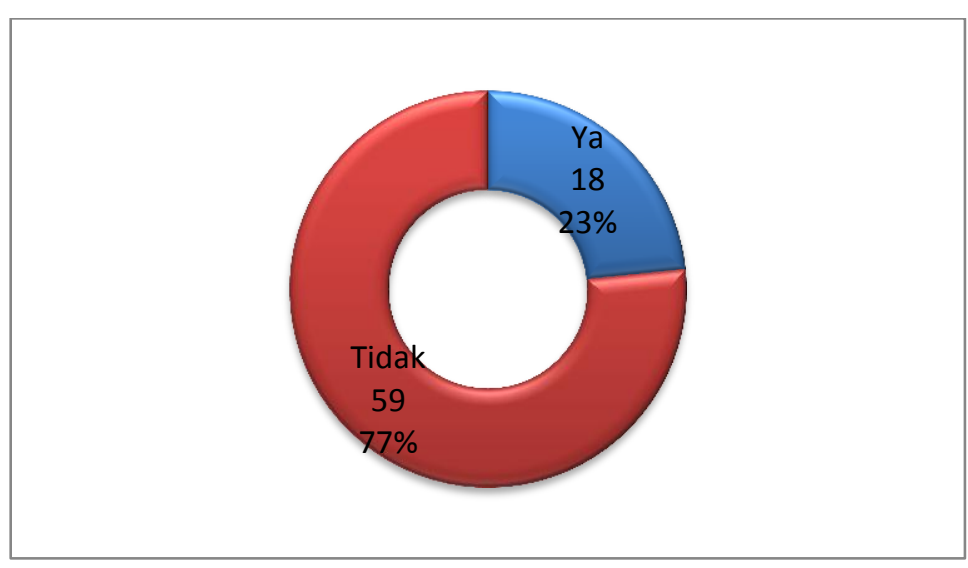

Sumber: Data primer diolah, 2014.

Gambar di atas menunjukkan bahwa rata-rata responden menginginkan untuk tidak mengalami hambatan karir terkait dengan ilmu yang diperoleh selama masa studi dengan bidang kerja saat ini. Mayoritas responden menyatakan tidak terhambat yaitu sebanyak 59 orang (77\%). Mereka merasa meskipun tidak semua mata kuliah terkait dengan masalah pekerjaan, akan tetapi masih terdapat beberapa mata kuliah tertentu yang masih berhubungan dan mempunyai relevansi dengan masalah pekerjaan saat ini. Beberapa mata kuliah yang disebutkan responden yang masih relevan dengan pekerjaan saat ini adalah manajemen keuangan, manajemen pemasaran, manajemen strategik, komunikasi bisnis, serta aplikasi komputer. Sementara responden yang mengalami adanya hambatan karir terkait dengan ilmu yang diperoleh dan masalah pekerjaan sebanyak 18 orang $(23 \%)$.

\section{Penutup}

Dari paparan tentang kondisi alumni, baik saat masih bertatus sebagai mahasiswa maupun setelah lulus, dan pendapat pengguna lulusan terhadap kinerja lulusan Prodi Perbankan Syariah IAIN Walisongo Semarang, dapat disimpulkan sebagai berikut: 
1. Alumni secara umum dapat terserap di dunia kerja dengan masa tunggu kerja yang normal yaitu sekitar 3 bulan setelah lulus sudah mendapat pekerjaan mereka yang pertama. Mayoritas dari alumni juga bekerja pada bidang pekerjaan yang sesuai dengan bidang studinya.

2. Alumni menganggap bahwa kurikulum yang dikembangkan oleh Prodi sudah baik. Hampir semua mata kuliah dasar inti yang diselenggarakan dinilai bermanfaat dalam menunjang pekerjaan mereka. Untuk metode PBM alumni menilai kegiatan tatap muka dikelas secara langsung dan kegiatan diskusi kelas, serta praktek di lapangan sangat penting dan bermanfaat.

3. Alumni menganggap kompetensi hard maupun soft yang mereka miliki dan peroleh selama belajar di prodi perbankan syariah sudah baik. Alumni menilai kompetensi softskill yang mereka miliki lebih tinggi dari pada hard skill mereka dan hal ini sesuai dengan kebutuhan dunia kerja yang semakin menuntut penguasaan soft skills. Namun jika diperbandingkan dengan harapan akan tuntutan kompetensi ditempat kerja masih ada sejumlah gap yang perlu ditingkatkan ke depan baik dalam hardskill maupun soft skill.

Berdasarkan temuan penelitian, dapat dikemukakan saran sebagai berikut.

1. Kemampuan bahasa asing, khususnya bahasa Inggris bagi mahasiswa perlu ditingkatkan, baik melalui kursus yang dilakukan secara individual maupun penyelenggaraan pelatihan oleh Prodi Perbankan Syariah. Untuk pelatihan yang diselenggarakan Prodi Perbankan Syariah sebaiknya dilaksanakan secara kolektif dengan prodi lain.

2. Koleksi bahan pustaka perlu dilengkapi, baik jumlah maupun jenisnya. Kecuali itu bahan pustaka juga perlu di-update secara terus menerus agar tidak ketinggalan.

3. Kontak antara lulusan dengan almamater perlu lebih diintensifkan, baik melalui pertemuan seperti seminar-seminar dan temu alumni maupun menggunakan media cetak dan elektronik.

4. Survey penelusuran alumni agar diperluas melalui media elektronik dan internet, seperti melalui website dan situs-situs resmi lainnya. 
Tracer Study Jurusan Perbankan Syariah

Penguatan jaringan dengan alumni harus digarap dengan serius mengingat para alumni mempunyai peran penting dan strategis bagi kemajuan prodi kedepan. Upaya menjalin relasi dengan alumni dapat dilakukan melalui komunikasi yang intensif melalui media-media on-line, maupun mengadakan gathering dengan alumni untuk mendapat feedback bagi penyempurnaan kegiatan PBM ke depan. Upaya yang dilakukan pihak fakultas harus bersifat mutual benefit, yang dapat menimbulkan kerinduan dan kebutuhan alumni untuk selalu menjalin keeratan dengan almamaternya karena mereka merasakan ada manfaatnya. Tracer study seperti ini perlu dilakukan secara berkala. Disamping fihak fakultas dapat memperoleh banyak masukan mengenai daya serap lulusan dan berbagai permasalahannya, melalui tracer study perguruan tinggi juga dapat terus menjalin hubungan dengan alumninya.

Sudah saatnya institusi pendidikan tinggi melaksanakan survey penelusuran alumni secara lebih serius. Data yang dihasilkan oleh Survei memiliki kontribusi yang penting bagi pengembangan institusi pendidikan tinggi. Selain itu, sudah saatnya institusi pendidikan tinggi berpegang pada hasil penelitian empiris bidang pendidikan tinggi dalam rangka pengambilan keputusan. Sangat sering kebijakan dalam dunia pendidikan berubah, misalnya dalam hal kurikulum, tanpa adanya pertimbangan dari data empiris hasil penelitian. Hal ini tentu saja merupakan hal yang ironis karena institusi pendidikan tinggi selalu dipandang sebagai pusat kegiatan ilmiah. Beberapa hal menjadi rekomendasi dari hasil tracer study ini adalah:

1. Beberapa kesimpulan hasil tracer study ini harus dijadikan umpan balik oleh Program Studi Perbankan Syariah untuk memperbaiki hal-hal yang dipersepsi kurang oleh alumni.

2. Tracer study perlu dilaksanakan secara berkelanjutan dengan melibatkan partisipasi unit kerja akademik secara lebih serius. Hal ini diperlukan agar response rate meningkat dan dapat memberikan data yang representatif secara statistik. Hasil analisis tentunya dapat digunakan untuk berbagai kepentingan, seperti akreditasi, perbaikan proses akademik dan lain-lain.

3. Program Studi Perbankan Syariah harus memperbaiki sistem pengelolaan data alumni yang terintegrasi dengan database yang ada. Tersedianya data alumni yang baik akan memudahkan Program Studi Perbankan Syariah dalam bersinergi dengan alumni untuk pengembangan institusi. 
4. Program Studi Perbankan Syariah perlu mengembangkan unit kerja yang menangani alumni ini secara lebih serius. Program Studi Perbankan Syariah perlu membentuk Pusat Jasa Ketenagakerjaan (PJK) dan perlu mendefinisikan kembali tugas pokok dan fungsinya dengan memasukkan pelaksanaan tracer study sebagai salah satu tugasnya. Tugas pokok tersebut sebaiknya diklasifikasikan menjadi tiga hal, yaitu (a) Menyelenggarakan upaya peningkatan softskills mahasiswa, (b) Menjadi interface antara alumni dengan dunia kerja dan (c) Menyelenggarakan penelitian untuk menjadi masukan perubahan kebijakan.

5. Perlu dilakukan analisis silang (crosstab) untuk melihat keterkaitan antar data. Selain itu perlu juga analisis yang lebih mendalam terhadap beberapa poin pertanyaan untuk mendapatkan gambaran yang lebih jelas terhadap beberapa masalah.

Pada pelaksanaan kegiatan tracer study hambatan utama yang dihadapi adalah tidak dimilikinya data alamat para alumni, sehingga pelaksana kegiatan mengambil keputusan untuk mengirim kuesioner ke berbagai instansi baik pemerintah maupun swasta yang diduga kuat terdapat alumni yang bekerja disana. Untuk mengatasi hambatan tersebut maka hasil dari tracer study ini diharapkan menjadi cikal bakal DATA BASE alumni, sehingga kedepan Jurusan akan memiliki data lengkap tentang alumni. 
Tracer Study Jurusan Perbankan Syariah

\section{DAFTAR PUSTAKA}

BAN-PT, Akreditasi Program Studi Sarjana. Jakarta: Departemen Pendidikan Nasional BAN-PT, 2008

Cabreera, AF., Weets, DJ., dan Zulick, BJ, Making an impact with alumni survey. San Francisco: Jossey-Bass, 2005

Dikti, "Wardiman Kembali Ingatkan Link and Match" diunduh dari http://www.dikti.go.id/old/index.php?option=com_content\&task $=$ view\&id $=73 \&$ Itemi $=54$

Gibson, J.L; J.M Ivancevich, \& J.H. Donelly, Jr, Organizations: Behavior, Structure, Processes. Plano: Business Publications Inc, 1988

Heidermann, Methodology and Methods of Tracer Studies: an Overview, 2009

Hernawan, A.H, Prinsip-prinsip Pengembangan Kurikulum. Jakarta: Rineka Cipta, 2002

Keputusan Menteri Pendidikan Nasional No.232/U/2000 tentang pedoman penyusunan kurikulum pedidikan tinggi dan penilaian hasil belajar kurikulum.

Keputusan Menteri Pendidikan Nasional Republik Indonesia Nomor 045/U/2002 tentang Kurikulum Inti Perguruan Tinggi.

Kominfo, "Perguruan tinggi tentukan kualitas ketenagakerjaan", diunduh dari http:/ / bipnewsroom.info/index.php?\&newsid $=57670 \& \_l i n k=$ load news.php

Majalah Human Capital, "Ada Apa dengan Kualitas Lulusan Perguruan Tinggi? Edisi 48 Maret 2008, www.portalhr.com/ beritahr/karir/detail.php? cid=1\&id =928\&page 1

Marwata, "Eksistensi Perguruan Tinggi Swasta", http://cetak.kompas.com/read/2009/10/14/11011932/eksistensi. perguruan.tinggi.swasta

Matteson, M.T. et.al, Management and Organizational Behavior Classics. Homewood: BPI/IRWIN, 1989

Melchiori, Alumni Research: Method and Application, San Francisco: Jossey-Bass, 1988

Milton, C.R, Human Behavior in Organization. Englewood Cliffs: Prentice Hall, Inc, 1981 
Minner, J.B, The Principle of Management. Columbus: Charles E.Merill Publishing Company, 1985

Nasution, S, Asas-asas Kurikulum, Jakarta: Bumi Aksara, 2003

Nazir, M, Metode Penelitian, Jakarta: Ghalia Indonesia, 1999

SEARCA, "Tracer study on SEARCA Fellows and UC Grantees", http://aau.org/studyprogram/web/scholarship, diakses 24 Agustus 2008.

Schomburg, Harald, Handbook for Graduate Tracer Studies: Centre for Research on Higher Education and Work, University of Kassel, Germany", http://www.qtafi.de/handbook_v2.pdf

Schomburg, Questionnaire Development, 2010

Setiawan, B dan Muntaha, A, Metode Penelitian Komunikasi II. Jakarta : Pusat Penerbitan Universitas Terbuka, 2000

Setneg, "Mengharmonisasikan Tenaga Kerja dan Pendidikan di Indonesia", diunduh dari situs http/www.setneg.go.id, 2010

Sudjana, N, Pembinaan dan Pengembangan Kurikulum di Sekolah. Bandung: Sinar Baru Algensindo, 2005.

Syafila, Mindriany, Tracer Study, Bandung: Warta Direktorat Pendidikan ITB, 2005

Vermeulen, The Study of Alumni: Professional Success, Commitment to University, and The Role of the Academic Learning Environment, Netherland: Lemma Publisher, 2006

Yasar, Iftida, "Link and Match: Keterkaitan Dunia Industri dan Dunia $\begin{array}{llll}\text { Pendidikan", diunduh dari } & \end{array}$ http://ilmusdm.,wordpress.com/2009/08/11/realita-link-matchdunia-usaha-dan perguruan- tinggi/, 2009

Zembere, S.N. dan Chinyama, MPM, The University of Malawi Graduate Tracer study 1996. http://aau.org/studyprogram/notpub. 24 Agustus 2008

WZI, Higher Education and Graduate Employment in Europe, 2000 
Tracer Study Jurusan Perbankan Syariah 